Rodzina, ekonomia i migracja. Ujęcie prawne i socjologiczno-ekonomiczne, red. Magdalena Butrymowicz, Piotr Kroczek, Kraków 2021, s. 155-170 (Biblioteczka Prawa, 4).

Klaudia Dudka

Klaudia Senderska

Agnieszka Klimczyk

Anna Mazurczyk

Paweł Ryndak

KOEO NAUKOWE STUDENTÓW PRACY SOCJALNEJ

UNIWERSYTET PAPIESKI JANA PAWŁA II W KRAKOWIE

\title{
Na wojnie ze stereotypami. Wyobrażenie pracowników socjalnych na temat pracy w środowisku wielokulturowym
}

\section{Wstęp}

Niniejszy artykuł przedstawia analizę wyników badań dotyczących wyobrażenia i opinii pracowników socjalnych odnośnie do grup wielokulturowych oraz pracy zawodowej z ich przedstawicielami. $\mathrm{Z}$ powodu powiększającego się obecnie grona odbiorców pomocy społecznej, pochodzących z różnych grup etnicznych czy mniejszościowych, oraz ze względu na rosnące zjawisko uchodźctwa i związane z nim konsekwencje i dylematy, Koło Naukowe Studentów Pracy 
Socjalnej UPJPII podjęło się zgłębienia tej tematyki. Przeprowadzone badania są także pierwszymi w historii Koła Naukowego, co jest istotną inicjatywą z punktu widzenia jego przyszłego rozwoju.

Na początku należałoby przybliżyć termin wielokulturowości, ściśle związany $\mathrm{z}$ badanym obszarem oraz wykorzystany $\mathrm{w}$ późniejszym procesie badawczym przy tworzeniu pytań kwestionariuszowych, jak i w analizie uzyskanych wyników. Według Mariana Golki jest ona definiowana jako koegzystowanie na tym samym obszarze kilku grup społecznych, które różnią się od siebie szczególnymi cechami. Tym, co w pierwszej kolejności je różnicuje, jest wygląd zewnętrzny. Jak później wymienia Golka, ważnymi czynnikami określającymi wielokulturowość są odmienny język oraz inne wyznanie religijne. Kolejną cechą wskazującą różnice między tymi grupami jest odrębny układ wartości. Wymienione kryteria są kilkoma $\mathrm{z}$ wielu innych, które można by tutaj wymienić, jednakże istotne dla nich wszystkich jest to, iż stanowią one podstawę do obserwowania różnic przez przedstawicieli tych społeczności $\mathrm{w}$ stosunku do innych, co prowadzi do różnych działań i ich konsekwencji ${ }^{1}$.

Do wyżej wymienionej definicji warto dodać tę przytoczoną przez Andrzeja Sadowskiego, wedle której wielokulturowość to pewien proces wzajemnego przenikania się kultur. W tymże znaczeniu wiąże się on także z interakcją między jej członkami lub zachodzeniem jednej kultury na drugą. Sadowski w swojej definicji podaje, że proces ten dokonuje się na poziomie zarówno społecznym, jak i kulturowym oraz charakteryzuje się obiektywizmem i ciągłą intensyfikacjąa ${ }^{2}$.

1 Zob. M. Golka, Imiona wielokulturowości, Warszawa 2010, s. 7-8.

2 Zob. A. Sadowski, Wielokulturowość jako czynnik zrównoważonego i inteligentnego rozwoju Polski, „Optimum. Studia Ekonomiczne” 2016 nr 4 (82), s. 73, DoI: 10.15290 . 
Celem przeprowadzonych badań była weryfikacja założenia, że pracownik socjalny, z uwagi na charakter wykonywanego zawodu, reprezentuje pozytywną postawę wobec Innego (w domyśle - przedstawiciela grupy wielokulturowej), oraz wykonywanej z nim pracy. Wydawać się może, iż określenie osoby o odmiennej kulturowości, obyczajach czy języku pojęciem „Inny” może mieć charakter pejoratywny, jednakże termin ten został wybrany przez autorów w sposób świadomy. Zabieg ten miał na celu nie tylko podkreślenie faktycznych różnic, ale przede wszystkim wywołanie określonej reakcji u respondenta, ujawniającej w sposób pośredni jego nastawienie do Innego.

Badania zostały przeprowadzone metodą ilościową, z uwagi na szerokie grono respondentów. Doboru próby dokonano celowo, wybierając grupę pracowników socjalnych. W tymże badaniu posłużono się techniką ankiety, toteż do jego przeprowadzenia wykorzystano narzędzie kwestionariusza ankiety. Odpowiedzi wśród opiniodawców zebrano zarówno w formie papierowej, jak i w postaci ankiety internetowej.

\section{Pracownik socjalny wykazuje pozytywną postawę wobec Innego i pracy $z$ nim}

\section{Postrzeganie Innego przez pracowników socjalnych}

W pierwszej kolejności, aby mówić o problematyce wielokulturowości, należało sprawdzić, co pracownik socjalny rozumie pod pojęciem Inny. Dodatkowo, poruszając się w temacie sposobu postrzegania Innego, należy pamiętać, iż w swojej ocenie pracownik socjalny może również kierować się szeregiem wpływów społecznych, takich jak wyznawane wartości i wiara, wychowanie, najbliższe otoczenie itp. 
Analizując wypowiedzi respondentów, można zauważyć, że rozumienie pojęcia Inności związane jest głównie z miejscem pochodzenia i różnicami w uwarunkowaniach społeczno-kulturowych (wykres 1). Dla osób badanych Inny oznacza osobę spoza granic naszego kraju.

Wykres 1. Inny to dla mnie... (\%)

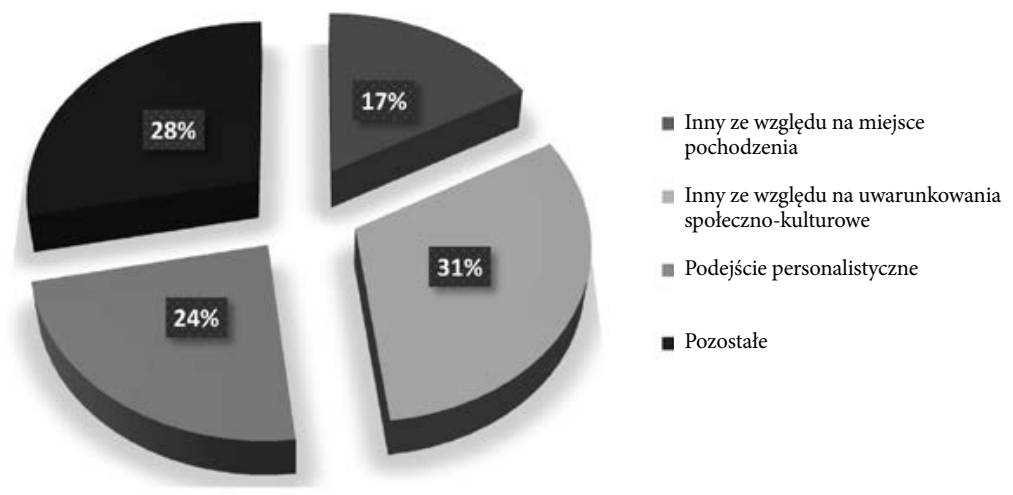

Źródło: Opracowanie własne.

Dodatkowo podkreślany jest także fakt, że pomimo różnic kulturowych czy społecznych Inny jest traktowany jako drugi człowiek, a więc uważa się go za podmiot, patrzy się nań z pozycji personalizmu. Co więcej, większość respondentów dostrzega wartość dodaną pracy z Innym, otrzymują bowiem w zamian wiedzę, która kształtuje ich zawodową i życiową postawę.

Na kolejnym wykresie (wykres 2), przedstawiającym pozytywne postrzeganie Innego przez pracowników socjalnych, widać, iż dominujące były odpowiedzi o charakterze społeczno-kulturowym (40\%). 
Wykres 2. Najlepsze w Innym jest to... (\%)

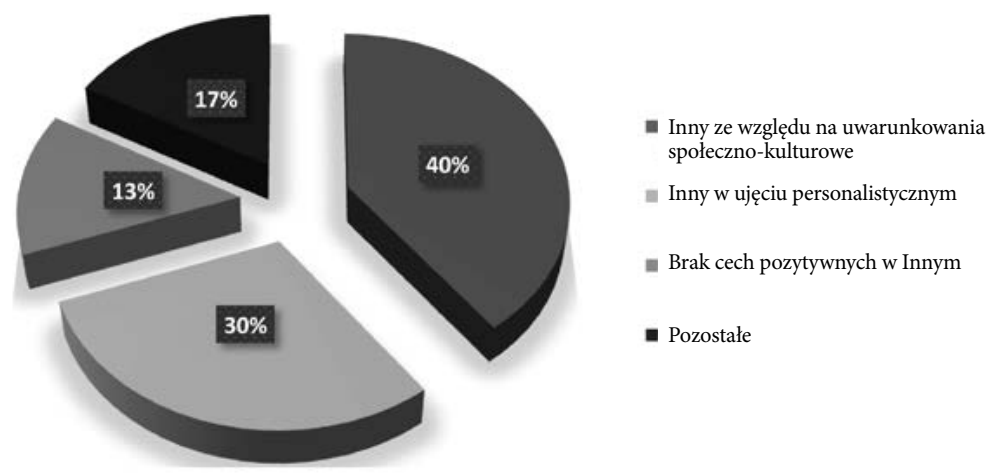

Źródło: Opracowanie własne.

W odpowiedziach respondentów pojawiają się także wzmianki o negatywnym postrzeganiu Innego (wykres 3). Jest to związane z zauważalną odmiennością, czyli jest niewpasowaniem się w powszechnie przyjęte kanony społeczno-kulturowe, na które składają się również wyznawane wartości i religia, a przede wszystkim wygląd zewnętrzny oraz język, którym posługuje się Inny. Uzyskane odpowiedzi pogrupowano ze względu na barierę w komunikacji, destruktywną postawę Innego oraz stereotypowe myślenie o nim. Da się zauważyć, że najczęściej wskazywanym określeniem Innego było „Obcy”. Respondenci za największą wadę Innego uznawali jego roszczeniowość, bierną postawę wobec konieczności zmiany oraz niechęć w przypadku podejmowania niezbędnych kroków w kierunku usamodzielnienia się i asymilacji. Negatywne spojrzenie na Innego oraz stereotypowe myślenie o nim mogą wynikać z obawy pracowników socjalnych przed tym, co nowe i nieznane. Zwłaszcza, jeśli napotykane w codziennej pracy problemy dotyczą nie tylko bariery językowej czy kultury i obyczajów, lecz także pełnego niechęci nastawienia u Innego. 
Wykres 3. Najgorsze w Innym jest to... (\%)

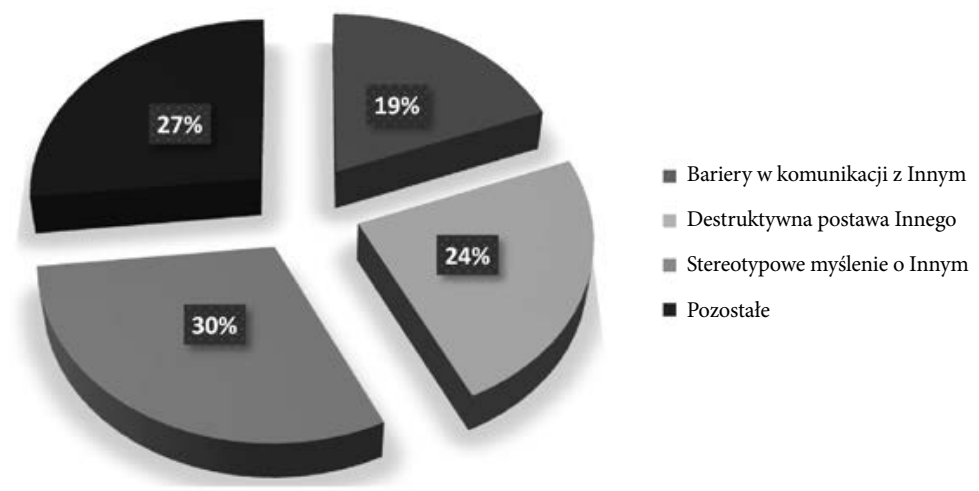

Źródło: Opracowanie własne.

W dalszej części badania respondenci zapytani zostali o potrzeby Innego i jego oczekiwania względem pracownika socjalnego co do świadczonej pomocy (wykres 4). Zebrane odpowiedzi dotyczyły najczęściej zniesienia barier komunikacyjnych, poprawy warunków socjalno-bytowych, zapewnienia wsparcia psychologicznego, konkretnego zestawu dostępnych usług, a przede wszystkim świadczenia realnej pracy socjalnej. Z analizy wynika, że Inny oczekuje od pracownika socjalnego wsparcia, zrozumienia, akceptacji, zapewnienia poczucia bezpieczeństwa i pomocy w osiągnięciu stabilizacji życiowej. Dla pracownika socjalnego stanowi to wyraźny dowód, że jest traktowany jako osoba kompetentna w dziedzinie organizacji wsparcia oraz osoba, która dostrzega w Innym nie klienta, lecz człowieka. 
Wykres 4. Inny najbardziej potrzebuje... (\%)

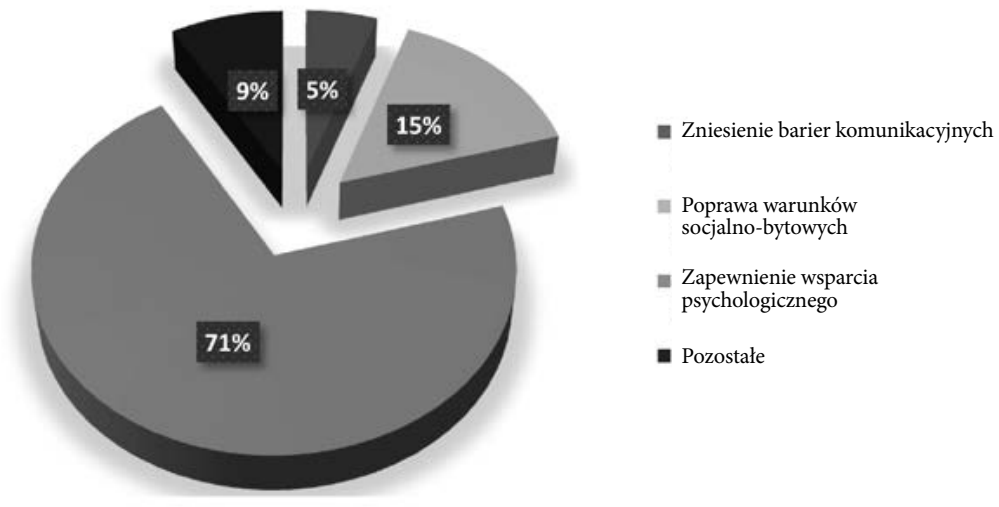

Źródło: Opracowanie własne.

Do najczęściej wymienianych usług należą: zapewnienie schronienia, zaspokojenie podstawowych potrzeb życiowych oraz, w głównej mierze, zapewnienie pomocy finansowej (wykres 5).

Wykres 5. Oczekiwania Innego od pracownika socjalnego w kontekście pomocy społecznej mogą dotyczyć... (\%)

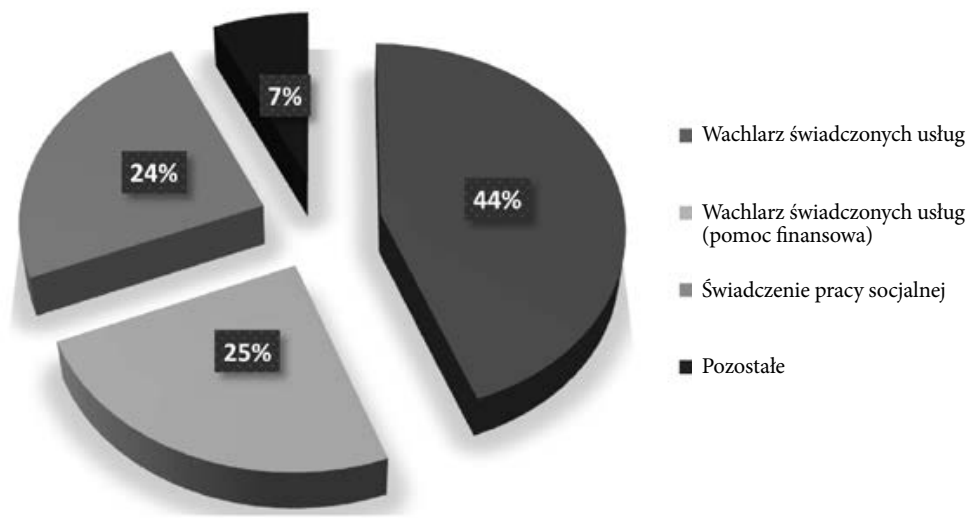

Źródło: Opracowanie własne. 


\section{Stosunek pracownika socjalnego do pracy z Innym}

Analizując wypowiedzi respondentów, można zauważyć, że ułatwieniem $\mathrm{w}$ pracy $\mathrm{z}$ Innym byłaby $\mathrm{w}$ pierwszej kolejności znajomość języka, kultury czy zwiększenie możliwości instytucjonalnych, poprzez konieczność poszerzenia oraz doprecyzowania norm prawnych i przepisów dotyczących pracy z Innym (wykres 6). Ponadto ankietowani wskazują, że poznanie kultury, z którą związany jest Inny, zwiększa możliwość skutecznej pracy w relacji pomocowej. Podkreślają również, że istotne jest to, aby Inny zaznajomił się z naszą kulturą. W niesieniu pomocy Innemu ankietowani stawiają na jego głębsze poznanie oraz podkreślają, że dużym ułatwieniem w tym względzie byłaby znajomość jego języka. Wskazują, iż wspólny język stwarzałby szansę nawiązania odpowiednich relacji pomocowych, co skutkowałoby możliwością udzielenia wsparcia w lepszej formie.

Wykres 6. Dużą pomocą w pracy z Innymi dla mnie byłoby... (\%)

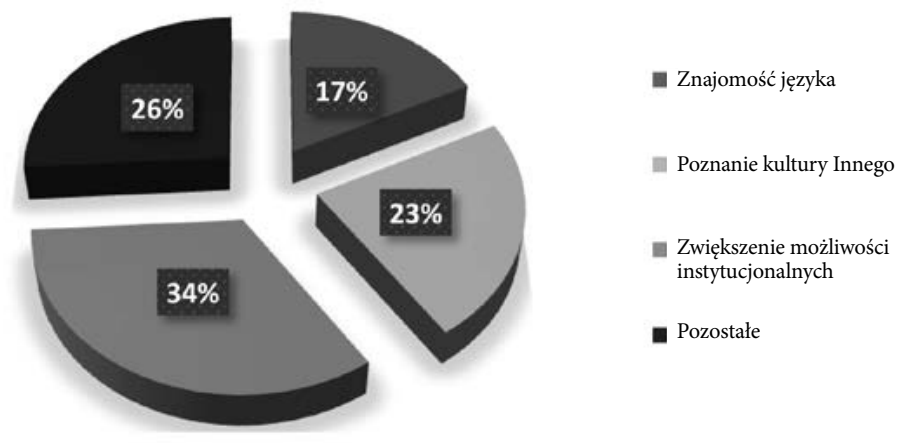

Źródło: Opracowanie własne.

Pracownicy socjalni dostrzegają kilka aspektów, dzięki którym pomoc Innemu może być bardziej skuteczna (wykres 7). Wśród nich można wyróżnić asymilację, wsparcie instytucjonalne, a także 
pozytywną postawę Innego wobec zmiany. Ankietowani zwracają uwagę, że największy sukces w pracy z Innym można odnieść w sytuacji, kiedy sam zainteresowany wykaże chęć i zaangażowanie w zmianę swojego trudnego położenia. Jest to ważny aspekt w budowaniu poprawnej relacji między pracownikiem socjalnym a klientem. Kolejną szansą, jaką wskazują respondenci, jest wsparcie instytucjonalne. Charakteryzuje się ono odpowiednią postawą pracownika socjalnego wobec Innego, co motywuje go do chęci poprawy swojej sytuacji życiowej. Respondenci zwracają również uwagę na fakt, że nie tylko instytucja ma duży wpływ na pomoc Innemu, ale także jego chęć integracji z naszym społeczeństwem. Przyczynia się to do poprawnych relacji z jednostkami, z którymi Inny na co dzień funkcjonuje.

Wykres 7. Największą szansą dla pomocy Innemu jest... (\%)

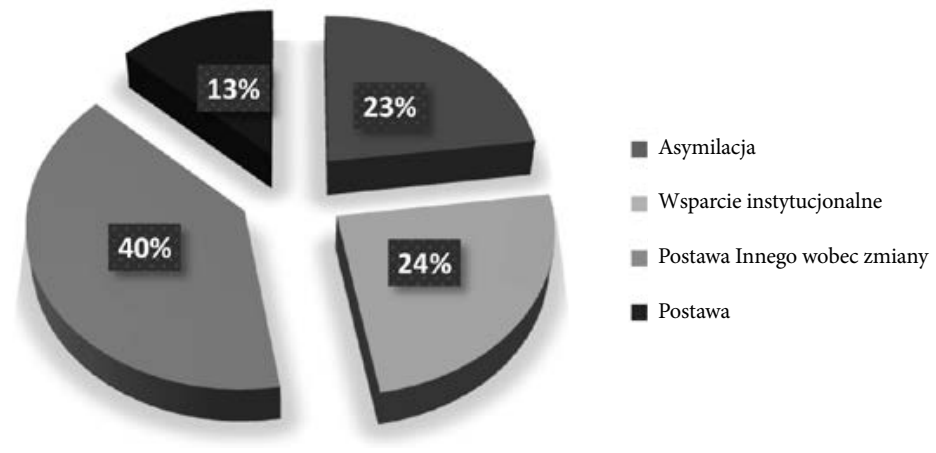

Źródło: Opracowanie własne.

Pracownicy socjalni wskazali, że w kontaktach z Innym najbardziej obawiają się jego negatywnej postawy, wynikającej z nieprzewidywalności jego zachowania. Chodzi tu głównie o roszczeniowość, brak współpracy czy agresję (wykres 8). Respondenci zwracają również uwagę, że brak zrozumienia wpływa na jakość budowania ich kontaktów z Innym. Przypuszczają, że Inny nie będzie w stanie odczytać 
poprawnie ich intencji, ukierunkowanych na poprawę jego funkcjonowania. $\mathrm{W}$ relacji z Innym ankietowani podkreślają też problem bariery językowej - utrudnione porozumienie implikuje niemożność poznania Innego, a w konsekwencji uniemożliwia udzielenie skutecznej pomocy. Poza wymienionymi powyżej kategoriami respondenci wskazali, że w ich opinii także odmienność kulturowa Innego może utrudnić nawiązanie kontaktu pomocowego.

Wykres 8. Najbardziej boję się w kontaktach z Innym... (\%)

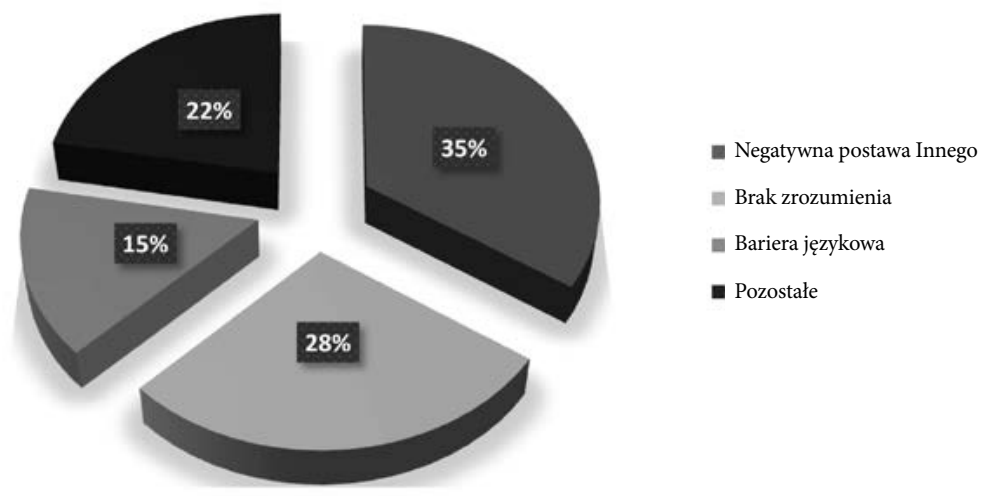

Źródło: Opracowanie własne.

\section{Identyfikacja pracownika socjalnego z Innym}

Respondenci zapytani o cechę Innego, jaką dostrzegają również u siebie, w większości zauważają, że posiadają cechy wspólne (wykres 9). Mają one wydźwięk pozytywny, a są to między innymi: godność ludzka, odwaga, determinacja czy otwartość. Część ankietowanych wskazuje, że nie ma żadnych cech wspólnych z Innym, co może wynikać również z braku udzielonych odpowiedzi. 
Wykres 9. Cechy Innego we mnie to... (\%)

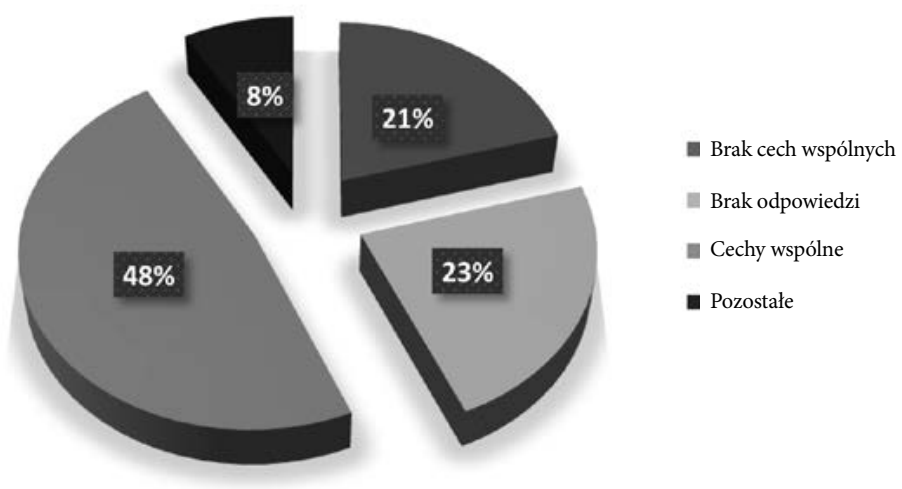

Źródło: Opracowanie własne.

Pracownicy socjalni w odpowiedzi na rozpoczęte zdanie, „Gdyby Inny był na moim miejscu, to...”, wskazywali głównie, że pozytywnym aspektem dla Innego byłby fakt posiadania pracy, co skutkowałoby bezpieczeństwem, stabilizacją oraz prestiżem społecznym (wykres 10). Zwracali uwagę na: ocenianie prestiżu posiadanego zatrudnienia, wykazywanie empatii, tak niezbędnej u wykonujących zawód pracownika socjalnego, zrozumienie potrzeb i problemów drugiej osoby, a także trudu wykonywania zawodu pracownika socjalnego oraz pogłębianie się zjawiska wypalenia zawodowego, którego można się doszukiwać w biernej postawie, a które np. może wiązać się odpowiedziami ankietowanych odnośnie do rezygnacji ze stanowiska pracy. 
Wykres 10. Gdyby Inny był na moim miejscu, to... (\%)

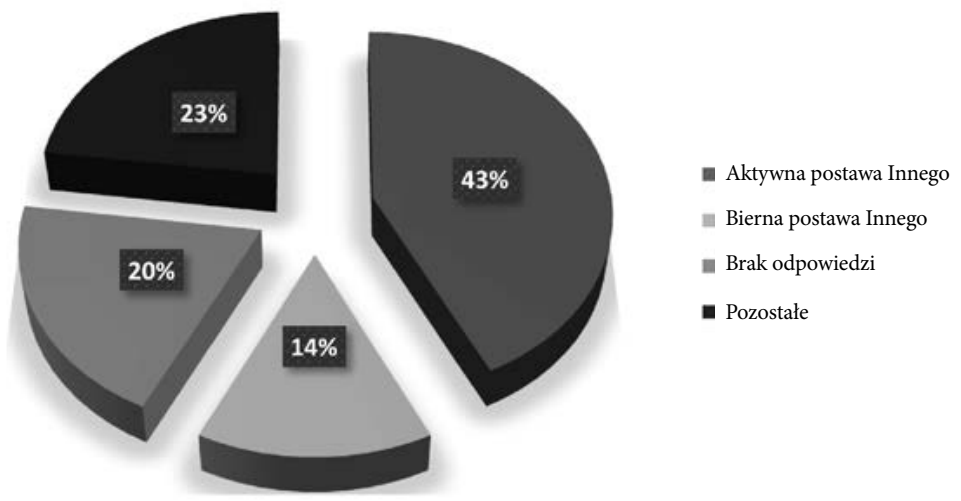

Źródło: Opracowanie własne.

\section{Opinia pracownika socjalnego na temat pomocy Innemu}

Ostatnie pytanie badawcze dotyczyło opinii pracowników socjalnych na temat pomocy Innemu. Zebrane odpowiedzi koncentrowały się wokół zmian w polityce społecznej, zachęcania do pozytywnego postrzegania Innego. Jednocześnie wskazano rozwiązania, które mogą być postrzegane jako negatywne, a w tym między innymi budzą niechęć do świadczenia pomocy, a w najgorszym wypadku moga prowadzić do deportacji. Pracownicy socjalni w swoich odpowiedziach zasugerowali konieczność zreformowania ustaw dotyczących świadczenia pomocy oraz wprost wypowiadali się o rozważaniu zmiany stanowiska pracy, co może bezpośrednio wiązać się z syndromem wypalenia zawodowego. Niezbędna ich zdaniem jest organizacja dodatkowych kursów i szkoleń podnoszących kompetencje zawodowe, znajomość języka oraz kultury i obyczajów. 
Wykres 11. Gdybym był/-a ministrem rodziny, pracy i polityki społecznej, zarządziłbym/zarządziłabym... (\%)
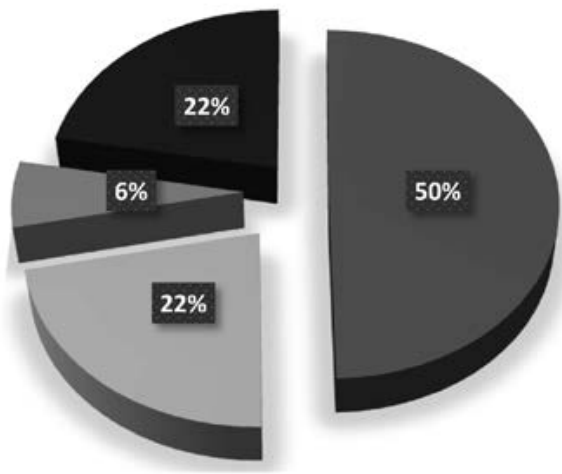

- Zmiany w polityce społecznej

|w Pozytywne postrzeganie Innego

- Negatywne postrzeganie Innego

Źródło: Opracowanie własne.

Dodatkowo analiza wypowiedzi respondentów wykazała, iż prawo do pomocy Innemu powinno być przede wszystkim powszechne, sprecyzowane i obligatoryjne.

Wykres 12. Prawo do pomocy Innemu powinno być... (\%)

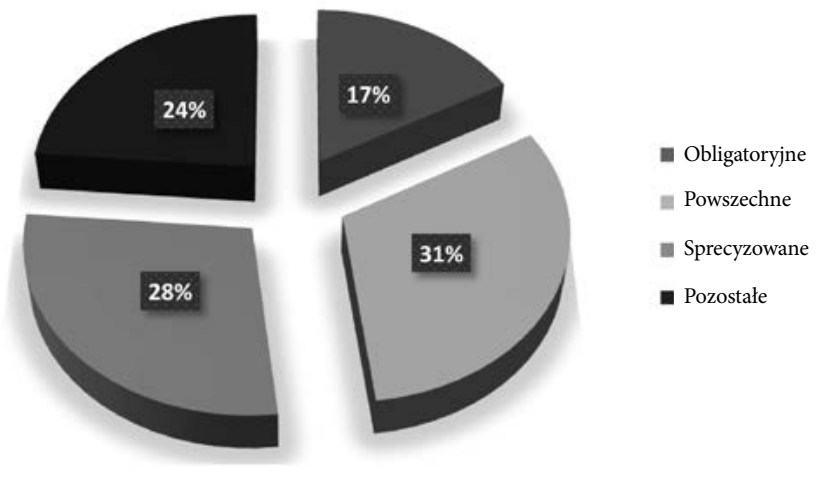

Źródło: Opracowanie własne. 


\section{Zakończenie}

Niniejszy artykuł przedstawił problematykę wielokulturowości, która coraz częściej związana jest z codziennymi obowiązkami pracowników socjalnych. Przedstawione wyniki badań pozwalają potwierdzić sformułowaną na wstępie hipotezę, która zakładała, że pracownik socjalny wykazuje pozytywną postawę wobec Innego i pracy z nim. Respondenci prezentują gotowość do pracy z nowym typem klienta, są go ciekawi, a także potrafią dostrzec korzyści, jakie odnoszą w tej pracy dla siebie samych.

Po dokonaniu analizy zebranego materiału można wysnuć kilka wniosków. Po pierwsze, pracownicy odbierają Innego w pozytywny sposób i są zdecydowani na udzielenie mu koniecznej pomocy. Inny nie jest dla nich wyłącznie obcokrajowcem czy uchodźcą, lecz osobą otrzymującą wparcie, tak jak każdy typowy klient ośrodka pomocy społecznej. Różnicę stanowią jedynie kultura czy język, jednak dla pracowników jest to bariera do pokonania, a nie trudność, która całkowicie niweluje możliwość świadczenia wsparcia. Postawa ta świadczy o pozytywnej motywacji profesjonalistów. Co więcej, jakiekolwiek obawy, które czują, wynikają z naturalnych odruchów ludzkich i dotyczą pierwszego spotkania z odmienną kulturą i obyczajami. Najtrudniejszym aspektem zdaje się być problem komunikacji i znajomości języka, przez który świadczone wsparcie może być mniej efektywne niż wobec poznanych już klientów ośrodka pomocy. Świadomość ta podkreśla jednak fakt, że pracownik socjalny w swoich obowiązkach kieruje się nie tylko zasadami wynikającymi z ustawy o pomocy społecznej, ale także własnym kodeksem moralnym i systemem wartości.

Każdy proces badawczy napotyka różnego rodzaju przeszkody, które zagrażają jego prawidłowemu przebiegowi. Niniejszy projekt stanowił niemałe wyzwanie ze względu na niewielkie doświadczenie 
organizatorów, także w przeprowadzeniu ankiet na tak szeroką skalę. Skutkowało to ograniczonym dostępem do ośrodków pomocy i niewielką liczbą arkuszy zwrotnych w pierwszej fazie. Po przeprowadzeniu ewaluacji zmniejszono liczbę respondentów, która początkowo wynosiła 250 osób, oraz zmieniono sposób realizacji badania z wyłącznie elektronicznych na wypełnianie osobiście w miejscu pracy bądź telefonicznie. Za sukces uznano zgromadzenie 131 odpowiedzi. Mając na uwadze, że badaniu zostali poddani pracownicy ośrodków na szczeblu gminnym, zaleca się rozszerzenie diagnostyki o kolejne województwa oraz rozważenie bardziej efektywnego sposobu zbierania danych. Wartość dodaną stanowi zebranie nowych doświadczeń jako badaczy i zapoczątkowanie w Kole Naukowym potrzeby dalszego rozwoju i działalności badawczej. Z pewnością wpłynął na to także odkryty w trakcie projektu problem wypalenia zawodowego wśród pracowników, którzy poza potrzebą zmiany prawa, jako pomoc dla siebie wskazywali także, niestety, konieczność zmiany zawodu.

\section{Streszczenie}

Celem niniejszej pracy jest przedstawienie opinii, wyobrażeń i refleksji pracowników socjalnych na temat pracy na rzecz osób ze środowisk wielokulturowych. Często taka osoba pozostaje na marginesie wspólnoty lokalnej, umieszczona tam przez innych członków tej społeczności. Nadaje jej się zazwyczaj etykietę „Inny”, co zdecydowanie ogranicza jej możliwość pełnej przynależności. Autorzy pracy po przeprowadzeniu badań metodą ankietową przy użyciu kwestionariusza ankiety, składającego się z dwunastu zdań niedokończonych, chcą przybliżyć opinie pracowników socjalnych na temat Innego w odniesieniu do relacji pomocowej, którą z nim budują. Analizując wyniki badań, chcą odpowiedzieć na pytanie badawcze sformułowane w toku procesu badawczego, które brzmi: Jak wygląda postrzeganie Innego przez pracownika socjalnego? Poniższy tekst jest skonstruowany wokół czterech problemów badawczych. W taki sposób artykuł przybliża postrzeganie Innego przez pracowników socjalnych, stosunek pracownika 
socjalnego do pracy z Innym, percepcję inności w sobie, a także opinię pracowników socjalnych na temat pomocy Innemu. Jednym z głównych wniosków z przeprowadzonych badań jest przekonanie, że pracownicy socjalni w przeważającej większości mają pozytywny obraz Innego, a w relacji pomocowej z nim chcą podjąć takie działania, które umożliwią udzielenie mu jak najskuteczniejszej pomocy.

Słowa kluczowe: pracownik socjalny, praca socjalna, pomoc społeczna, stereotypy, środowisko wielokulturowe, wykluczenie społeczne, piętno społeczne

\section{Summary}

At war with stereotypes. Social workers' perception of working in a multicultural environment

This work aims at presenting social workers' opinions, perceptions and reflections on the work towards people coming from the multicultural environment. Such person often remains in local community margins as a result of being placed there by other members of this community. Such person is usually given a label "the Other" which strongly limits their capacity for full affiliation. After conducting survey research, using questionnaire survey, composed of twelve incomplete sentences, the authors of the work want to provide a closer insight into the social workers' opinions about "the Other," concerning aid based relationship built between the workers and "the Other." When analysing the research results, the authors want to answer the research question that was formed during the research process. This questions is: "How is "the Other" perceived by the social worker?" The text below is constructed around four research problems. In such a way this article gives a closer insight into the social workers' perception of the Other; social workers' attitude towards working with the Other; the perception of otherness in oneself; and also social workers' opinions on helping the Other. One of the main conclusions from the conducted research is a belief that social workers, in the great majority, have a positive image of the Other and in the aid based relationship they want to undertake such actions that will allow them to provide the most effective help.

Keywords: social worker, social work, social assistance, stereotype, multicultural environment, social exclusion, social stigma 